Available online at GSC Online Press Directory

GSC Biological and Pharmaceutical Sciences

e-ISSN: 2581-3250, CODEN (USA): GBPSC2

Journal homepage: https://www.gsconlinepress.com/journals/gscbps

(RESEARCH ARTICLE)

\title{
Antifungal and antioxidant activities of Carapa procera oil and its physicochemical characteristics
}

Serges Gbamelé Kouakou Kan ${ }^{1}$, Guillaume Yayé Yapi ${ }^{2,}$, , Valerie Bonouman Ira Ama ${ }^{3}$, Maurice Anigbé Amon ${ }^{1}$, Olivier Chatigre Kouamé ${ }^{1}$ and Joseph Djaman Allico ${ }^{1,3}$

${ }^{1}$ Université Félix Houphouët-Boigny (UFHB) Abidjan Cocody, 22 BP 582 Abidjan 01.

${ }^{2}$ Heath Biology, Université Jean Lorougnon Guédé (UJLoG) Daloa, Bp 150 Daloa.

${ }^{3}$ Institut Pasteur de Côte d'Ivoire (IPCI), 01 BP 490 Abidjan 01.

Publication history: Received on 27 January 2020; revised on 14 February 2020; accepted on 17 February 2020

Article DOI: https://doi.org/10.30574/gscbps.2020.10.2.0025

\begin{abstract}
Carapa procera oil is traditionally used for various pathologies including dermatoses. This study evaluates two the method of extraction of oil. The physicochemical characteristics, the antioxidant activity, and the antifungal properties were conducted respectively according to the ISO methods, DPPH method, and disc method plates while a phytochemical screening was performed by the colouring method, and the Thin Layer Chromatography (TLC). The results revealed that the iodine, saponification and refraction index vary from 68.50 to $73.11 \mathrm{gI} / 100 \mathrm{~g}, 197.70$ to 198 $\mathrm{mgKOH} / \mathrm{g}$ and 1.46 respectively. The antioxidant activity ranged from 715.8 to $115.3 \mathrm{mg} / \mathrm{mL}$ and the inhibition diameters on the fungal germs revealed 18 to $21 \mathrm{~mm}$ for Candida albicans strains and 23 to $25 \mathrm{~mm}$ for Trichophytic isolates. The presence of terpenoids, flavonoids, sterols and alkaloids have been proven. The extraction solvent assisted method retain the antioxidant activity and antifungal activity.
\end{abstract}

Keywords: Oil; Antifungal; Antioxydant; Physicochemical Characteristics; Screening

\section{Introduction}

The vegetable oil obtained from oilseeds not only plays an important role in human nutrition and in industries, but also in the economy of the producing countries as well. Most edible oils are obtained from so-called conventional plants such as, palm seeds, sunflower, olive etc. Besides this group of conventional oilseed plants, there are unconventional oilseeds which represent a very important part of the Africa's non-timber forest products [1]. The fruits of these plants contain 40-60\% fat. They are invisible sources of lipids and could thus constitute a potential raw material for oil mills [2].

Several of these plants have been studied to determine the physicochemical characteristics of their fat content [1,2]. Among these is the species Carapa procera, a tropical plant that grows in hot, humid areas.

The oil of this species is known for its anti-inflammatory properties [3]. It is used as anti-mosquito ointment [4], antimalarial [5], against termites [6] against dermatophytes [7]. It is also used in cosmetology for the production of soap in the treatment of skin and hair care [8].

Given the importance of this oil, this present study aims, in addition to the determination of the physicochemical characteristics, to evaluate its antioxidant and antifungal properties according to two extraction methods.

\footnotetext{
${ }^{*}$ Corresponding author

E-mail address: yayeyapi@yahoo.fr Phone: +225 08114855
} 


\section{Material and methods}

The biological material consisted on one hand, of the oil obtained from the seeds of Carapa procera, and on the other hand microorganisms made up of three fungal germs, they are: 5 strains of Candida albicans (656, 657, 661, 667 and 669), and 2 isolates (Trichophyton mentagrophytes and Trichophyton soudanense) selected because of their mucocutaneous pathogenicity. These germs isolate were provided by the mycology department of the Institut Pasteur of Côte d'Ivoire (IPCI).

The oil used in this study was extracted by two methods:

On one hand solvent assisted method was used according to ISO 659 [9]. In a balloon containing some pumice stones previously dried in an oven and cooled in a desiccator, $150 \mathrm{~mL}$ of hexane was added. In a cartridge, $10 \mathrm{~g}$ of crushed Carapa procera seeds were introduced and fixed to Soxhlet. Continuous extraction was performed at $60^{\circ} \mathrm{C}$ for 6 hours. At the end of this process, the hexane was removed in a rotavapor and then in an oven at $103{ }^{\circ} \mathrm{C}$ for $10 \mathrm{~min}$. The oil obtained are named H1F and H1V respectively, when used in the few days following its extraction and when used 6 months later.

And on the other hand, in a traditional extraction method, in this case after harvesting and sorting out, the nuts of good quality are boiled in water until softening of the hull. The nuts were then removed from the hulls and put in piles and then fermented for a week. They were then stripped of their integument and crushed. The resulting paste was roasted in a fire pot with the addition of water gradually. The oily portion was recovered and dried in an oven for three hours at $103{ }^{\circ} \mathrm{C}$. The oil, thus obtained are named $\mathrm{H} 2 \mathrm{~F}$ and $\mathrm{H} 2 \mathrm{~V}$ when used immediately for the microbiological tests and when used after 6 months respectively.

Furthermore, the determination of the physicochemical characteristics was performed to determine the following parameters: density and the $\mathrm{pH}$ according to the UICPA method [10], and that of Afane et al., [11] respectively. As well as peroxide's index, refraction, iodine and saponification. These parameters have been determined according to the methods described in the ISO standard of 3960 [12], ISO 3657 [13], ISO 6320 [14], and ISO 3961 [15] respectively. And the parameters such as color and acidity have been determined according to ISO 27608 [16] and ISO 660 [17] respectively.

Furthermore, a phytochemical screening performed at the same time made it possible to identify the chemical compounds contained in this oil extract. This screening was carried out using the conventional colouring reactions and by Thin Layer Chromatography (TLC) with the solvent mixture dichloromethane/ethyl acetate/hexane $(2 / 0.5 / 1)$ $(\mathrm{V} / \mathrm{V} / \mathrm{V})$ as eluent. Sterols and terpenes have been revealed by Liebermann-Bürchard's reagent, and Godin's reagent has revealed sterols, terpenes and flavonoids. Subsequently the antioxidant activity was determined using the spectroscopic assay (DPPH), and the colour intensity was measured in a spectrophotometer.

Thus, during this experiment, a concentration range of $1000,800,600,400,200,100,50 \mathrm{mg} / \mathrm{mL}$ was prepared from the oils incorporating chloroform. To a volume of $0.1 \mathrm{~mL}$ of each of these concentrations was added $3.9 \mathrm{~mL}$ of a 0.06 mM DPPH solution in methanol (prepared extemporaneously). The absorbance of the mixture was measured at 515 $\mathrm{nm}$ after $20 \mathrm{~min}$. A solution of $\alpha$-tocopherol, DDPH and methanol were used as a control. The antioxidant activity was determined by the ratio: [(OD DPPH-OD oil) / (OD DPPH)] $\times 100$.

Furthermore $\mathrm{IC}_{50}$ and $\mathrm{IC}_{90}$ values were determined graphically. The antimicrobial tests were performed using the disc diffusion method, paper disc were impregnated with Carapa procera oil at a concentration of $200 \mathrm{mg} / \mathrm{mL}$, on the surface of an agar medium previously inoculated by flooding with a fungal inoculum Candida albicans of 24 hours or Trichophyton of 5 days of culture with an optical density between 0.12 and 0.15 (1-5.106 $\mathrm{CFU} / \mathrm{mL})$.

Indeed, after flooding, the boxes were put in an oven at $25^{\circ} \mathrm{C}$ for $15 \mathrm{~min}$ before the dropping of $6 \mathrm{~mm}$ diameter disks impregnated and sterilized by autoclave for 1 hour. Subsequently the whole was incubated for $18-24 \mathrm{~h}$ at $37^{\circ} \mathrm{C}$ for Candida strains and $5-7$ days at $25{ }^{\circ} \mathrm{C}$ for Trichophyton isolate. The sensitivity of the fungal strains was evaluated with the usual molecules, Miconazole $50 \mu \mathrm{g}$ (MCZ50), Amphotericin B $100 \mu \mathrm{g}$ (AB100), Ketoconazole $50 \mu \mathrm{g}$ (KET50), and Clotrimazole $50 \mu \mathrm{g}$ (CTR50) according to the same protocol. Thus, the diameter of the zone of inhibition makes it possible to appreciate the sensitivity and the activity of the oil. The strain is sensitive if the diameter is $\geq 10 \mathrm{~mm}$.

In addition, the antifungal parameters Minimum Inhibitory Concentration (MIC) and Minimum Fungicidal Concentration (MFC) were respectively determined in liquid medium for the MIC by turbidity and then in agar medium for the MFC. In fact, in a series of 6 hemolytic tubes numbered from $T_{1}$ to $T_{6}, 1 \mathrm{~mL}$ of the pure inoculum was 
introduced and then $1 \mathrm{~mL}$ of concentrated oil extract 200, 100, 50, 25, 12.5 and 6.75. Separately, two control tubes, one for growth control and the other for medium sterility control were prepared. In other to facilitate the miscibility of the oils in the liquid medium, the Tween 80 has been used.

After inoculation all test tubes and control tubes were incubated at $37{ }^{\circ} \mathrm{C}$ for 24 hours for Candida albicans and 5-7 days for Trichophyton isolate. The MFC values were determined after reading the value of the MIC value and then seeding its content on a petri dish agar medium following inoculum dilution of $10^{\circ}, 10^{-1}, 10^{-2}, 10^{-3}$ and $10^{-4}$.

The software STATISTICA 8.0 was used for analysis of variance and comparison of averages with the Newman-Keuls test at the significance level $(\mathrm{P}<5 \%)$.

In addition, the ed50V10 software made it possible to determine the $\mathrm{IC}_{50}$ and $\mathrm{IC}_{90}$ values for the antioxidant capacity of each oil.

\section{Results}

The results concerning the physicochemical characteristics of the oils are presented in Table 1. Some parameters compared according to the extraction method used are identical: density, $\mathrm{pH}$, the peroxide value, the saponification value, the refractive index. On the other hand, other parameters such as colour, acidity, iodine value and impurity showed a significant difference at $\mathrm{P}<0.05$.

With regard to phytochemical screening, we observed that the oil extracted by both methods contained terpenoid, sterol, flavonoid and alkaloids.

As for the antioxidant activity, the $\mathrm{IC}_{50}$ value of the oil extracted traditionally was $715.8 \pm 5.00 \mathrm{mg} / \mathrm{mL}$ against 1151.3 $\pm 3.00 \mathrm{mg} / \mathrm{mL}$ for the oil extracted with solvent. The IC 90 values of the two oils are $1429.1 \pm 2.00 \mathrm{mg} / \mathrm{mL} \mathrm{and} 2351.2 \pm$ $0.55 \mathrm{mg} / \mathrm{mL}$ for the conventional oil and the solvent extracted oil respectively (Table 1).

Table 1 Physicochemical characteristics of oils extracted

\begin{tabular}{lll}
\hline Physicochemical parameters & Conventional oil & Solvent extracted oil \\
\hline Density at $20^{\circ} \mathrm{C}$ & $0.91 \pm 0.01 \mathrm{a}$ & $0.91 \pm 0.07 \mathrm{a}$ \\
Refraction index at $20^{\circ} \mathrm{C}$ & $1.46 \pm 0.01 \mathrm{a}$ & $1.46 \pm 0.01 \mathrm{a}$ \\
Saponification value $(\mathrm{mg} \mathrm{KOH} / \mathrm{g})$ & $197.70 \pm 0.01 \mathrm{a}$ & $198.00 \pm 0.02 \mathrm{a}$ \\
Peroxide value $\left(\mathrm{meq} \mathrm{O}_{2} / \mathrm{kg}\right)$ & $2.89 \pm 0.04 \mathrm{a}$ & $3.09 \pm 0.05 \mathrm{a}$ \\
$\mathrm{pH}$ at $20^{\circ} \mathrm{C}$ & $4.54 \pm 0,01 \mathrm{a}$ & $5.2 \pm 0.01 \mathrm{~b}$ \\
Colour at $60^{\circ} \mathrm{C}$ & $9.10 \pm 0.01 \mathrm{~b}$ & $6.2 \pm 0.01 \mathrm{a}$ \\
Iodine value $\left(\mathrm{gI}_{2} / 100 \mathrm{~g}\right)$ & $73.11 \pm 0.06 \mathrm{~b}$ & $68.50 \pm 0.03 \mathrm{a}$ \\
Acidity & $12.72 \pm 0.05 \mathrm{~b}$ & $2.88 \pm 0.04 \mathrm{a}$ \\
Impurity $(\%)$ & $0.28 \pm 0,02 \mathrm{~b}$ & $0.13 \pm 0.01 \mathrm{a}$ \\
\hline
\end{tabular}

$(a, b)$ The letters followed by the same figure on the same line are identical

In addition, antifungal activity showed inhibition diameters of $19.33 \pm 0.29$ to $24.00 \pm 1.00$ on Candida albicans strains and Trichophyton isolate with H1F extract. With the H1V extract, the values vary from $18.67 \pm 0.58$ to $23.00 \pm 0.80$ in all fungal germs. As for the $\mathrm{H} 2 \mathrm{~F}$ and $\mathrm{H} 2 \mathrm{~V}$ oil extracts, the values revealed are $18.00 \pm 0.50$ to $25.33 \pm 1.33$ and $18.50 \pm$ 1.50 to $25.00 \pm 1.20$. On the same microbial strain, the diameters are statistically identical at $(\mathrm{P}<0.05)$. They form a homogeneous group according to the Newman-Keuls test at the threshold ( $\alpha=5 \%$ ) (Table 2). 
Table 2 Antifungal activity of Carapa procrera oil

\begin{tabular}{llllllll}
\hline $\begin{array}{l}\text { Type } \\
\text { of oil }\end{array}$ & Candida albicans & & & & $\begin{array}{l}\text { Trichophyton } \\
\text { mentagrophytes }\end{array}$ & $\begin{array}{l}\text { Trichophyton } \\
\text { soudanense }\end{array}$ \\
\cline { 2 - 8 } & $\mathbf{6 5 7}$ & $\mathbf{6 5 6}$ & $\mathbf{6 6 1}$ & $\mathbf{6 6 7}$ & $\mathbf{6 6 9}$ & Clinical isolates & \\
$\mathrm{H}_{1} \mathrm{~F}$ & 20.00 & 19.67 & 21.33 & 21.00 & 19.33 & $24.00 \pm 1.00^{\mathrm{a}}$ & $21.67 \pm 1.53^{\mathrm{a}}$ \\
& $\pm 2.00^{\mathrm{a}}$ & $\pm 1.53^{\mathrm{a}}$ & $\pm 1.52^{\mathrm{a}}$ & $\pm 1.00^{\mathrm{a}}$ & $\pm 0.29^{\mathrm{a}}$ & & \\
$\mathrm{H}_{1} \mathrm{~V}$ & 20.50 & 20.33 & 20.17 & 21.83 & 18.67 & 23.00 & 20.67 \\
& $\pm 2.59^{\mathrm{a}}$ & $\pm 1.15^{\mathrm{a}}$ & $\pm 1.04^{\mathrm{a}}$ & $\pm 0.76^{\mathrm{a}}$ & $\pm 0.58^{\mathrm{a}}$ & $\pm 0.80^{\mathrm{a}}$ & $\pm 2.08^{\mathrm{a}}$ \\
$\mathrm{H}_{2} \mathrm{~F}$ & 21.17 & 20.00 & 20.67 & 19.50 & 18.00 & 25.33 & 24.33 \\
& $\pm 2.02^{\mathrm{a}}$ & $\pm 1.73^{\mathrm{a}}$ & $\pm 2.08^{\mathrm{a}}$ & $\pm 1.80^{\mathrm{a}}$ & $\pm 0.50^{\mathrm{a}}$ & $\pm 1.33^{\mathrm{a}}$ & $\pm 1.15^{\mathrm{a}}$ \\
$\mathrm{H}_{2} \mathrm{~V}$ & 21.00 & 20.83 & 20.83 & 20.00 & 18.50 & 25.00 & 23.67 \\
& $\pm 1.65^{\mathrm{a}}$ & $\pm 2.02^{\mathrm{a}}$ & $\pm 1.26^{\mathrm{a}}$ & $\pm 0.50^{\mathrm{a}}$ & $\pm 1.50^{\mathrm{a}}$ & $\pm 1.20^{\mathrm{a}}$ & $\pm 1.10^{\mathrm{a}}$ \\
\hline
\end{tabular}

$(a, b)$ The figures followed by the same letter in the column are identical

In addition, the MIC values of the $\mathrm{H} 1 \mathrm{~F}$ and $\mathrm{H} 2 \mathrm{~F}$ oils are $25 \mathrm{mg} / \mathrm{mL}$ for Candida albicans and $50 \mathrm{mg} / \mathrm{mL}$ for Trichophyton mentagrophytes. MFC values are $100 \mathrm{mg} / \mathrm{mL}$ for Candida albicans and Trichophyton mentagrophytes and $200 \mathrm{mg} / \mathrm{mL}$ for Trichophyton soudanense (Table 3). Concerning the usual molecules, the inhibition diameters are represented in the table 4.

Table 3 Antifungal parameters MIC and MFC of the different oils

\begin{tabular}{lllllll}
\hline Type of oil & \multicolumn{2}{l}{$\begin{array}{l}\text { Candida } \\
\text { albicans }\end{array}$} & & \multicolumn{2}{l}{$\begin{array}{l}\text { Trichophyton } \\
\text { mentagrophytes }\end{array}$} & Trichophyton soudanense \\
\cline { 2 - 7 } & MIC & MFC & MIC & MFC & MIC & MFC \\
H1F & 25 & 100 & 25 & 100 & 50 & 200 \\
H2F & 25 & 100 & 25 & 100 & 50 & 200 \\
H1V & nd & nd & nd & nd & nd & nd \\
H2V & nd & nd & nd & nd & nd & nd \\
\hline
\end{tabular}

Table 4 Diameter of zones of inhibition for the usual antifungals

\begin{tabular}{llll}
\hline Usual molecules & \multicolumn{3}{l}{ Inhibition Diameters } \\
\cline { 2 - 4 } & $\begin{array}{l}\text { Candida } \\
\text { albicans }\end{array}$ & $\begin{array}{l}\text { Trichophyton } \\
\text { mentagrophytes }\end{array}$ & $\begin{array}{l}\text { Trichophyton } \\
\text { soudanense }\end{array}$ \\
\hline MCZ 50 & $26-38(\mathrm{~S})$ & $28(\mathrm{~S})$ & $28(\mathrm{~S})$ \\
CTR 50 & nd & $19(\mathrm{~S})$ & $18(\mathrm{~S})$ \\
AB100 & nd & $7(\mathrm{R})$ & $7(\mathrm{R})$ \\
KET50 & nd & $14(\mathrm{~S})$ & $12.5(\mathrm{~S})$ \\
\hline \multicolumn{5}{r}{ nd : not determined } & S: Sensitive & R: Resistant
\end{tabular}

In addition, the characterization of the microorganisms is based on the correlation between the parameters the synthetic factors also the projection of the fungal germs in the factorial plane. Thus, the extracts (H1F, H1V, H2F, H2V) giving a negative correlation at factor 1 (axis1) accumulate $86.90 \%$ of the total variance. The correlation coefficients (r) are: - 0.95; - 0.86, - 0.95; - 0.96 for H1F, H1V, H2F and H2V respectively. As for the factor 2 
(axis 2) the H1V extract is negatively correlated with $r=-0.48$; while the H2F extract is positively correlated to this same factor with $r=0.30$. This factor contributes $9.97 \%$ of the total variance. It is from these correlations between the variables and the factors ( 1 and 2 ) that the dispersion of the strains in the factorial plane or dispersion plane (Figure 1 ) is interpreted. Thus, we distinguished 4 groups of germs' sensitivities according to the extracts tested (Figure 2):

- Group 1 consisted of the 4 strains of Candida albicans 661,656,657,669, is characterized by germs sensitive to all the oils extracts either extracted in a traditional way, or with the solvent, either fresh or old.

- Group 2 consisted only of the Candida albicans 667 strain. It is characterized by a slightly more pronounced sensitivity to the solvent extraction oil (H1) than the traditional extraction oil (H2).

- Group 3 consisted of the Trichophyton mentagrophytes isolate with same sensitivity to all oils (H1 and H2).

- and Group 4 consisted only of the Trichophyton soudanense isolate has a higher sensitivity to H2 (traditional extracted oil) than to $\mathrm{H} 1$ (solvent extracted oil).

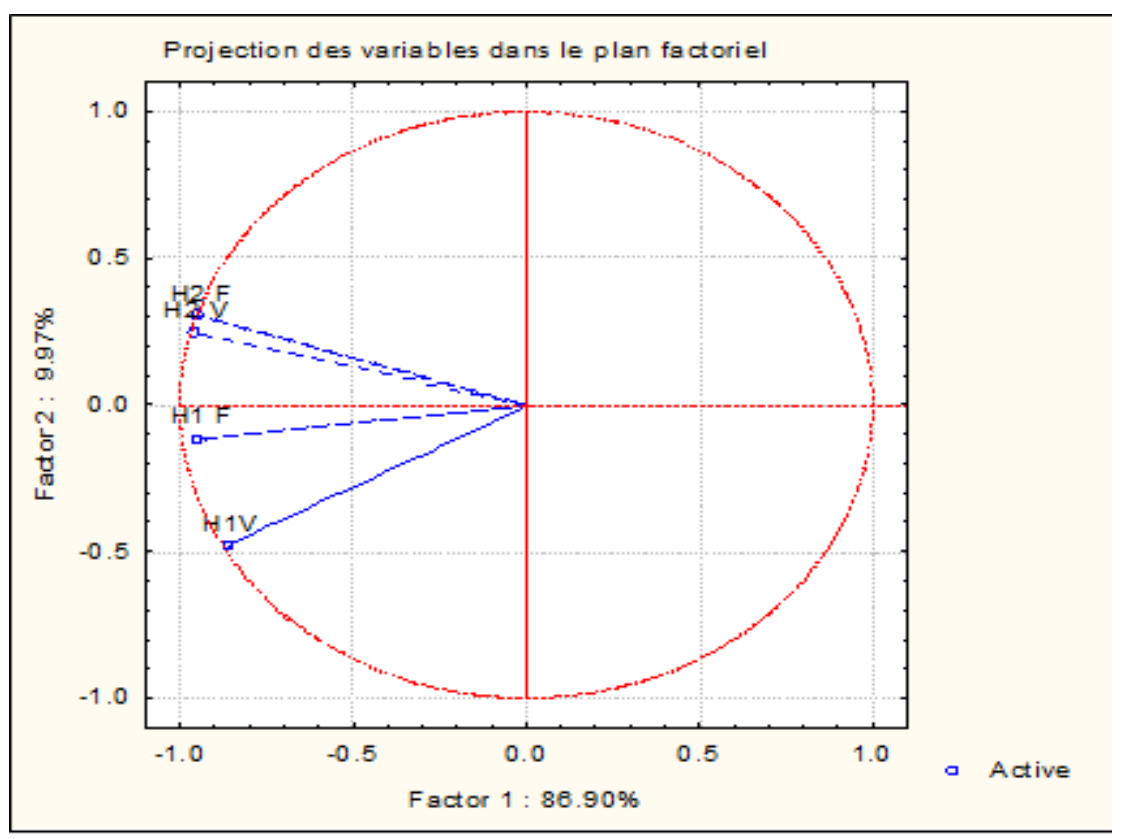

Figure 1 Correlations variables- principal factors 


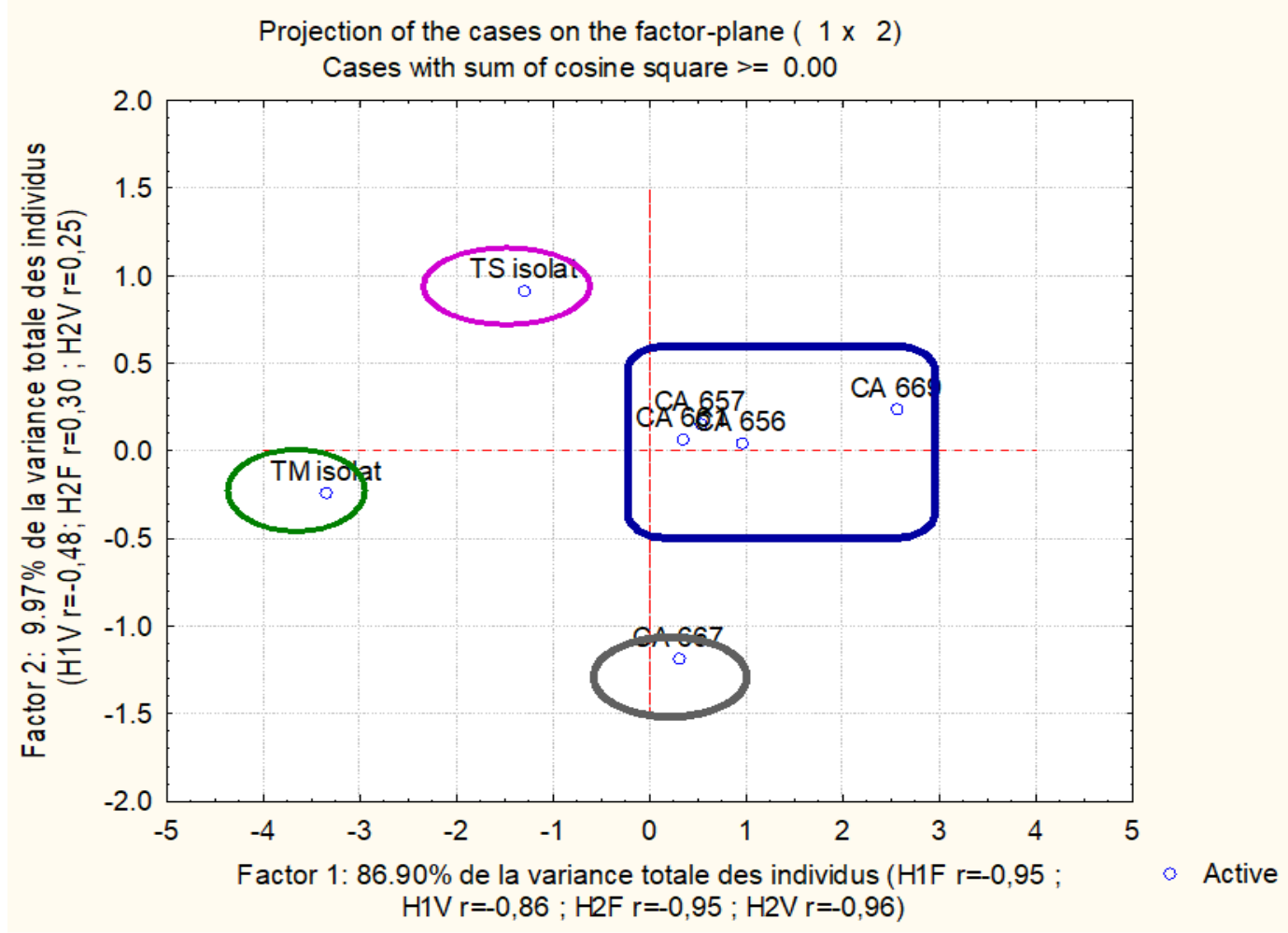

Figure 2 Microorganisms group determined by ACP

TM : Trichophyton mentagrophytes isolate ; TS : Trichophyton soudanense isolate

CA656, CA 657, CA661, CA667, CA669 (Candida albicans strains 656, 657, 661, 667, 669).

\section{Discussion}

The physicochemical characterization has shown that the physicochemical parameters such as refractive index, density, saponification value and peroxide value are statistically identical in oils obtained from the two extraction methods. Unlike the parameters; colour, iodine value, acidity, $\mathrm{pH}$, impurity which is statistically different. The variation in the saponification and iodine values highlighted in our study had been confirmed by other studies. According to some authors, these values vary from 188-201 for the saponification value and 61.80-73.00 for the iodine value $[3,6]$. The present study has shown that the saponification value of Carapa procera oil is statistically equivalent to that of other oilseeds such as jatropha (199), cotton (195) and palm oil 196-205 [18]. As for the iodine value obtained, is higher than that of palm oil whose values ranged between 50-55 [19] and which represents the most consumed oil in the world [20]. The results obtained could justify the use of Carapa procera oil in the production of soap. In addition, the iodine value (68-73) revealed that Carapa procera oil is more fluid compared to palm oil (50$55)$.

In addition, the acidity of the traditional extracted oil was 12.72 which is much higher than that of the solvent extracted oil (2.88). This acidity is linked to the fermentation of oil seeds during the 7 days, thus causing a hydrolysis of fatty acids.

On the other hand, the peroxide values of 2.89 meq $\mathrm{O}_{2} / \mathrm{kg}$ and 3.09 meq $\mathrm{O}_{2} / \mathrm{kg}$ obtained for $\mathrm{H} 2$ and $\mathrm{H} 1$ respectively revealed that our oils have been less oxidized. This is in line with the recommendations of $15 \mathrm{meq} \mathrm{O}_{2} / \mathrm{kg}$ for nonrefined oil [4]. As for the characteristics such as refractive index (1.458) and density (0.9081), they are identical to those obtained by Mutinsumu et al. [21].

Regarding the antioxidant activity, analysis revealed that oils extracted by the traditional methods (H2) and solvent assisted (H1) have IC50 of $715 \mathrm{mg} / \mathrm{mL}$ and $1149.6 \mathrm{mg} / \mathrm{mL}$ respectively. It turns out that $\mathrm{H} 2$ oil has the best antioxidant capacity. This could be due to the process of obtaining the H1 oil that would be related to excessive 
heating. Indeed, according to Ferreira et al. [22], heating during a solvent extraction could be responsible for the reduction in the antioxidant capacity of the oil.

As for the antifungal properties of Carapa procera oil on the growth of Candida albicans strains, Trichophyton mentagrophytes and Trichophyton soudanense strains, the study showed that this oil inhibits their growth.

This antifungal activity is more intense on the Trichophyton mentagrophytes and Trichophyton soudanense isolates. Moreover, the inhibition diameters of fungal germs with extracts of Carapa procera are lower than those of Miconazole. However, when it comes to the molecules of Ketoconazole, Amphotericin B and Cotrimazole, the diameters of inhibition are lower than those obtained with these same oils. Considering the works of Biyiti et al., in 2004 [23], an extract is considered active if the diameter of the zone of inhibition is greater than or equal to $10 \mathrm{~mm}$. Therefore, in view of the values obtained with the Carapa procera oil extracts, it follows that these extracts are active on the fungal germs tested. This justifies its traditional use against dermatoses.

In addition, thin-layer chromatography and conventional colouring tests have revealed terpenoid, flavonoid, sterol and alkaloid. These results corroborate with those of Dioum et al., in 2013 [3]. The antimicrobial capacity of Carapa procera oil would be related to the presence of these compounds that are known for their antimicrobial properties that act through a synergistic action.

\section{Conclusion}

The study of the physicochemical, antioxidant and antifungal properties of the Carapa procera oil has shown that not only the values of the parameters obtained confirm those of conventional oleaginous materials but also the antifungal effects of these oils on dermatoses. They also justify the fluidity of this oil, as well as its use in local soap production. Moreover, these properties are preserved in view of the activities of the extracts (fresh or old).

In addition, the extraction of this oil according to the solvent assisted method also retains the essential biological properties of this oil (anti-radical effects and antimicrobials). It would be necessary to perform bioguided extraction to improve on antifungal and anti-radical activity and isolate the molecules responsible for this antifungal activity of the oil.

\section{Compliance with ethical standards}

\section{Acknowledgments}

We would like to express their deepest gratitude to the entire staff for the Clinical and Fundamental Biochemistry Department and the Department of Parasitology-Mycology of Institut Pasteur.

\section{Disclosure of conflict of interest}

The authors declared no conflict of interest.

\section{References}

[1] Silou T. (2014). Corps gras non conventionnels du Bassin du Congo: Caractérisation, biodiversité et qualité. OCL, 2 (2), 2-15.

[2] Kapseu C, Tchankou Leudeu BC, Tchiegang C, Silou T and Parmentier M. (2005). Rapport sur quelques propriétés physico-chimiques des huiles de quelques oléagineux non conventionnels en Afrique au sud du Sahara, 8-11.

[3] Dioum MD, Seck M, Sy GY, Faye J M, Sarr A, Faye B and Faye B. (2013). Activité anti-inflammatoire de la graine de Carapa procera- (Meliaceae). Revue Sciences des Structure et de la Matière, 1, 17-28.

[4] Sylla M, Konan L, Doannio JMC and Traoré S. (2003). Évaluation de l'efficacité de lotions et de crèmes à base d'huiles de coco (Cocos nucifera), de palmiste (Eleais guineensis) et de gobi (Carapa procera) dans la protection individuelle contre les piqûres de Simulium damnosum s.l. en Côte d'Ivoire. Bulletin de la Société de Pathologie Exotique, 96(2), 104-109. 
[5] Osei-Djarbeng N, Agyekum-Attobra E, Nkansah R, Solaga D, Osei-Asante S and Owusu-Dapaah G. (2015). Medicinal plants constituting antimalarial herbal preparations in the Ghanaian Market. British Journal of Pharmaceutical Research, 5(3), 153-162.

[6] Djenontin TS, Amusant N, Dangou J, Wotto DV, Avlessi F, Dahouénon-Ahoussi E, Lozano P, Pioch D and Sohounhloué KCD. (2012). Screening of Repellent, Termiticidal and Preventive activities on Wood, of Azadirachta indica and Carapa procera (Meliaceae) seeds oils. Journal of Biological Sciences, 1(3), 25-29.

[7] Diatta CD, Gueye M and Akpo LE. (2013). Les plantes médicinales utilisées contre les dermatoses dans la pharmacopée Baïnounk de Djibonker, Région de Ziguinchor (Sénégal). Journal of Applied Biosciences, 70, 55995607.

[8] Ouédraogo A, Lykke AM, Lankoandé B and Korbéogo G. (2013). Potentials for promoting oil products identified from traditional knowledge of native trees in Burkina Faso. Journal of plants, people and applied research, 11, 71-83.

[9] ISO 659. (2009). Graines oléagineuses. Détermination de la teneur en huile (méthode de référence).

[10] UICPA. (1987). Méthodes d'analyse des matières grasses et dérivés. Tec \& Doc, Paris, 190.

[11] Afane E, Lando G, Biyiti L and Atchou G. (1997). Les vapeurs de palme bouillante, un acide broncho-irritant. Médecine d'Afrique Noire, 44, 604-607.

[12] ISO 3960. (2007). Corps gras d'origines animale et végétale. Détermination de l'indice de peroxyde.

[13] ISO 3657. (2002). Corps gras d'origines animale et végétale. Détermination de l'indice de saponification.

[14] ISO 6320. (2000). Corps gras d'origines animale et végétale. Détermination de l'indice de Réfraction.

[15] ISO 3961. (1996). Corps gras d'origines animale et végétale. Détermination de l'indice d'iode.

[16] ISO 27608. (2010). Corps gras d'origines animale et végétale. Détermination de la couleur Lovibond® Méthode automatique.

[17] ISO 660. (2009). Corps gras d'origines animale et végétale. Détermination de l'indice d'acide et de l'acidité.

[18] Djenontin ST, Dangou J, Wotto DV, Sohounlhoue KCD, Lozano P and Pioch D. (2006). Composition en acides gras, stérols et tocophérols de l'huile végétale non conventionnelle extraite des graines de Jatropha curcas (euphorbiaceae) du Benin. Journal de la Société Ouest-Africaine de Chimie, 22, 59-67.

[19] Codex alimentarius. (1999). Norme pour les huiles végétales Programme mixte FAO/OMS sur les normes alimentaires FAO (Codex Stan 210-1999) Rome.

[20] Battaglia M. (2010). Noyé dans l'huile de palme, l'explosion de la demande mondiale. Le Monde Magazine, №39.

[21] Mutinsumu M, Taba KM, Silou T, Tshiombe M and Buluma MK. (2015). Chemical characterization of vegetable oils from some non-conventional oleaginous plants of Democratic Republic of the Congo. International Journal of Agricultural and Food Science, 5 (1), 21-26.

[22] Ferreira BS, De Almeida CG, Faza PL, De Almeida A, Galuppo CD, Da Silva VL, Grazul RM and Le Hyaric M. (2011). Comparative properties of Amazonian oils obtained by different extraction methods. Molecules, 16 (7), 5875-5885.

[23] Biyiti LF, Meko'o DJL, Tamzc V and Amvam ZPH. (2004). Recherche de l'activité antibactérienne de quatre plantes médicinales camerounaises. Pharmacopée et Médecine Traditionnelle Africaine, 13, 11-20.

\section{How to cite this article}

Serges GK, Guillaume YY, Valerie BI 3, Maurice AA, Olivier CK and Joseph DA. (2020). Antifungal and antioxidant activities of Carapa procera oil and its physicochemical characteristics. GSC Biological and Pharmaceutical Sciences, $10(2), 130-137$. 